\title{
UNITY OF THEORY AND PRACTICE IN THE PROMOTION OF PRESCHOOL CHILD'S MUSICALITY IN THE TEACHER'S AND CHILD'S COLLABORATION
}

\author{
Anna Liduma \\ University of Latvia, Latvia
}

\begin{abstract}
This scientific article involves holism, anthropological and action methodological approaches. The article includes theoretical substantiations based on J. Greata's (2006) concepts of the musical activity impact on the child holistic entirety development, B.Vikmane (1995) and L. Mackevicha's (1999), Latvian preschool music scientists, conceptions about music content and A. Liduma's (2004-2016) researches in the child musicality (emotional responsiveness, musical hearing, sense of rhythm, musical memory and musical thinking, voice vocal range and singing skill) development promotion possibilities through the teacher and the child collaboration in the preschool music sessions. The empiric research analyzes the integrity of theory and practice in the music teacher pedagogical action at the integrative music session at preschool with 3-6-year-old children in $x$ primary school at the preschool interest education. Conclusions are drawn that the child's positive attitude to his/her musicality development is promoted due to the scientifically substantiated music content accordant to the children needs, the teacher's orientation and skill to create in equality based collaboration with children.
\end{abstract}

Keywords: action, child's musicality, collaboration, preschool.

\section{Introduction}

The scene of the past 20 years in preschool pedagogy shows irreversible changes having been occurred in preschool pedagogy and preschool music pedagogy in the world in general. They have affected Latvia as well. It is to be noted that due to globalization and experience exchange influence in various projects, the teachers' perceptions of values have changed, which undeniably affects the attitude of the younger generation towards music in preschool education in Latvia.

The changes taking place during school year 2019/2020 in Latvia due to implementation of the project School 2030 (Pirmsskolas mācību programma, 2019) imply the music researcher/scientist (the author of this article) to indicate to project promoters the necessity of following the principle of unity of theory and practice for the sake of sequence of child's musicality development at Preschool educational institution. 
Liduma, 2020. Unity of Theory and Practice in the Promotion of Preschool Child's Musicality in the Teacher's and Child's Collaboration

It is necessary because child's (3-7 years) self-experience in general, and in particular in musical activity, is low. Often it lacks at all, if musical environment at home corresponding to child's age has not been ensured, as parents have little interest in child's musical activity for various reasons.

The different students' attitudes to music as observed during lectures make it possible to confirm teacher's work significance, as only engaging activities could possibly encourage teachers-to-be to make use of musical activities throughout the run of a whole day at preschool educational institutions in the future.

Observations during course of the annual conferences of Latvia's preschool music education association (from year 2010) demonstrate the diverse attitude of music teachers towards the values of Latvian folk music, i.e., folk music in general and folk song as a means of promoting the musicality and citizenship of a preschool child. It is important to remind that preschool children's attitude to musical values depends on the work of a skilled teachers' team at a preschool education institution. Understandably, the music content must meet the actual needs of the child, including Latvian folk music, which was compiled by the whole nation and is a unique and unrepeatable value .

The preschool pedagogical process in Latvia till 2017/2018 school year was organized purposefully on the above mentioned basis. Holistic development is being promoted by the child's personally significant action, by self-realization of the inborn need to explore the world during observation and imitation processes. The teacher's support at Preschool is significant for the formation of the child's habits and self-regulation.

The empiric research reveals interpretation of observations and interviews at the annual conferences of Latvia's preschool music education association during 10 years and the paper's author self-experience analysis about the pedagogical collaboration at music game play studies with 3-7 years old children and discussions with parents. This research explores collaboration for promotion of the child musicality as a personally significant value in the process of collaboration between a teacher and a child.

The aim of the study: to analyze theory and practice unity in the collaboration of a music teacher and a child at preschool education of interests as a means to promote child's musicality.

\section{Literature review: Theoretical basis of the child's musicality}

The theoretical basis of this research are findings about collaboration as a teaching and learning method and upbringing principle by Maurice Balson (1995), Ausma Shpona's (2006) upbringing theory about the teacher's position to collaboration, Christopf Wulf's (2007) anthropological approach to the human's 
development at a definite place and time, Joanne Greata's findings about necessity to promote musicality during early childhood (years 0-8) and Anna Liduma's (2004, 2015, 2017) research about the content of preschool music sessions.

The theoretical substantiation of the article is the conclusion of Boris Teplov that the basic components of musicality are emotional responsiveness, hearing and the sense of rhythm, which is confirmed by the article author's observations in the pedagogical practice of the music teacher (Teplov, 1947). Singing and voice vocal range are fostered as well in a targeted and systematic action. Musical action promotes the child's musical memory and musical thinking (Liduma, 2004).

Blazma Vikmane, the first Latvian scientist in Preschool music pedagogy, wrote about the significance of the teacher's action in her dissertation already in 1995. Therefore, it is important for all teachers to be musically educated and to help the child perceive music, to create a positive attitude towards music, promote children's musical action and children's musicality in general, as emphasized in Linda Mackevicha's promotion work in 1999. To be able to carry it out professionally, all preschool teachers need to acquire the theory of collaboration essence, accept the value of collaboration, so that collaborative skills can be used in practice. The content of this article highlights collaboration as a social and personally significant value, which has the potential to influence the child's musicality and the attitude of the child towards musical action as a whole.

It is necessary to mention that during this research preschool pedagogical process was organized according the regulations No 533 "Regulations of state education guidelines" by Ministry of Education and Science and the Cabinet of Ministers (CM), as of 17 August 2012 (Noteikumi par..., 2012). In order to maintain the principles and needs of the child's psychic development processes, the children's comprehensive (balanced physical, psychic, social) and harmonious (balanced intellectual, emotional, will) development is being promoted, knowledge, skills and attitudes needed for individual and social life are being taught at preschool for further use at elementary school (Liduma, 2017; Liduma, 2018).

Musicality is formed at a particular place and time for each child according to his/her inherited capacities. Taking into account the holistic approach to the child's musical development, A. Liduma has defined musicality. Musicality is an integrated personality trait, consisting of emotional perception and emotional responsiveness, musical hearing, sense of rhythm, voice vocal range, singing quality, musical memory and musical thinking (Liduma, 2004). Emotional responsiveness is the basic indication and core of musicality (Teplov, 1947). The ability to respond emotionally as an innate quality, promoted by an ageappropriate content in a child-friendly environment, forms musicality as a personality trait (Liduma, 2004). 
Liduma, 2020. Unity of Theory and Practice in the Promotion of Preschool Child's Musicality in the Teacher's and Child's Collaboration

Relying on Ch. Wulf's anthropologic methodology approach on human development at a particular place, time and space (Wulf, 2007), a 13-year's study (years 2004-2016) examined the relationships between the ability to respond emotionally and the formation of musicality, and it was found that there is a mutual correlation between them. A unit of the causes and effects of two or more pedagogical facts or phenomena in a new quality is a correlation. Relationships can exist and do not interfere with each other. Thus, musicality and emotional responsiveness are mutually reinforcing and influencing each other (Liduma, 2015).

Musicality is being developed gradually in the musical environment of the family (Vikmane, 1995; Mackevicha, 1999; Lìduma, 2004). The timely start of a child's musical activity in home's musical environment is important. Attitudes towards oneself, others, people, nature, work, culture and the state form in the collaboration of a child, parents, grandparents, peers and teachers. This is illustrated in the model (see Figure 1).

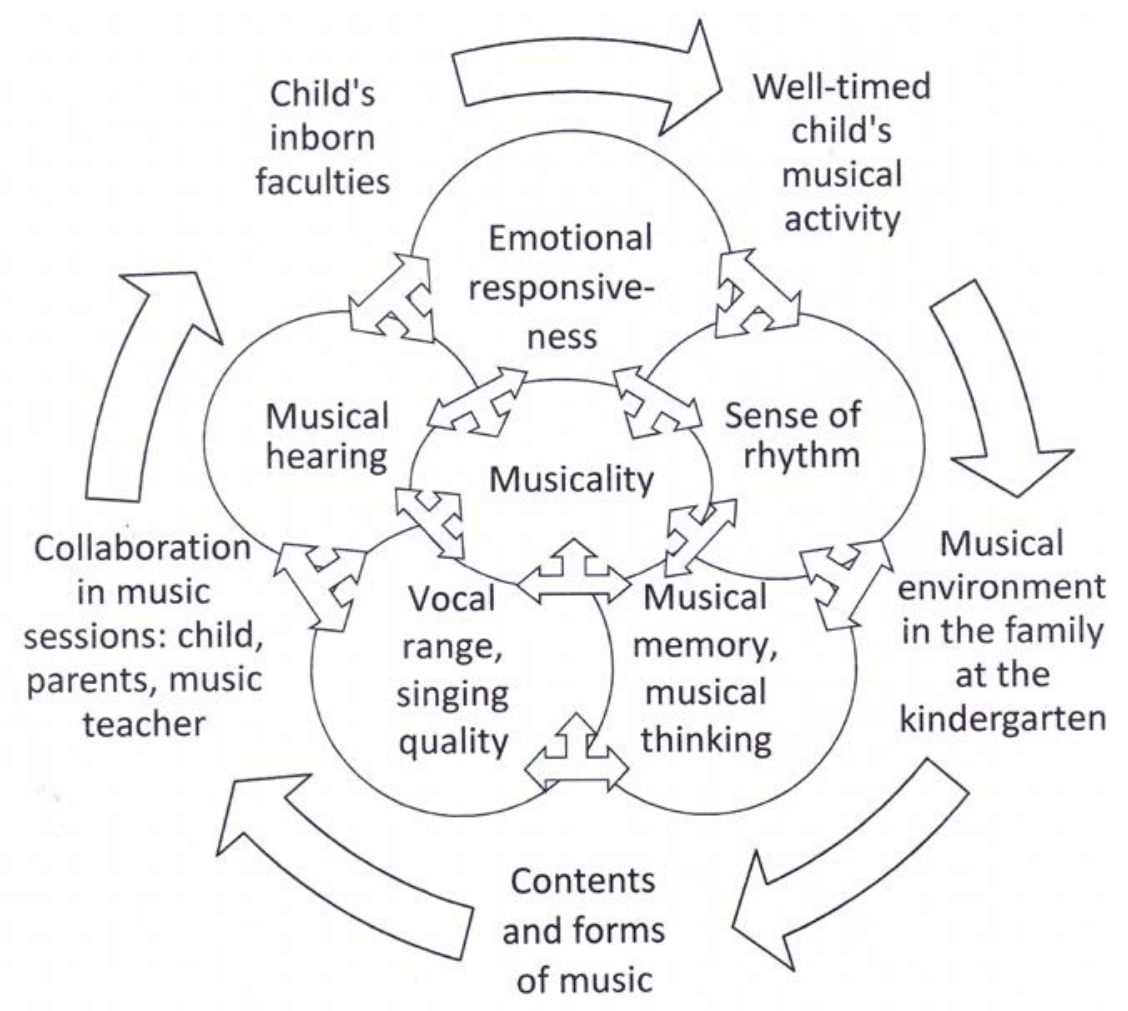

Figure 1 Model of child's musicality development in action (Lìduma, 2015)

The development of the child's musical thinking is of particular importance. In the course of a gradual empirical study, the child's musical thinking indicators were formulated:

1) wants to talk about music; 
2) wishes to listen music repeatedly;

3) shows interest in the names of the notes;

4) wishes to write notes;

5) is able to characterize the mood of music;

6) characterizes musical expression means (Līduma, 2015).

It is important that the theory and practice of playwork recognises that children's play should ideally be "freely chosen, personally directed and intrinsically motivated" (Playwork principles, 2004/2015). Therefore, equal collaboration between a teacher and a child is important at game play music sessions.

\section{Discussion: A child and teacher collaboration content in a musical activity}

The quality of collaboration among children, parents and teachers is important in preschool educational practice. Parental patience, persistent and independent children action and targeted teacher support are required. During the empirical study, it was examined and concluded that emotional responsiveness as a hereditary quality is the basic feature of musicality and a musicality center promoted by musical pedagogical means. By child's emotional response to the musical activity, the volume (range) of his/her vocal voice and the quality of singing (interest in singing and singing skills) gradually develop during his/her lifetime. The range is influenced by the child's inborn potentials, and the voice vocal range and singing quality of each child develops at an individual pace (Liduma, 2015).

From 1986 to 2016, while working as a music teacher in the interest education musicality promoting group with preschool children, the teacher's experience at preschool was systematically reflected and analyzed. It was found that an authoritarian style of work is not acceptable in pedagogical work, as it impedes the child's emotional responsiveness and limits creativity, because the aim of the teacher's work is to teach songs. An authoritarian teacher forces to do and demands unconditional obedience. It limits the child's independence and promotes passivity.

Observations revealed that preschool children with a low social experience remain aloof from such teachers and do not want to sing along. Due to the negative experience acquired at preschool, children are not responsive to musical activity at school.

The attitude of a liberal teacher in children as well leads to an uncritical approach to their activities. Failure to plan their time prevents children from exercising systematic musical activity, because the child's self-organized musical activity is necessary. 
Liduma, 2020. Unity of Theory and Practice in the Promotion of Preschool Child's Musicality in the Teacher's and Child's Collaboration

In the music classes of interest education in Latvia, observing the children's response to the teacher's musical action, it was found that a democratic style of the teacher's work is necessary. In the daily work of the music teacher it manifests as the promotion of a preschooler development in collaboration with the child in singing along. Therefore, for each musical class, the teacher together with the children, sets the goal and chooses the means appropriate to the needs of the child: content, diverse methods and forms.

Lev Vygotsky's theory about the actual zone of the child's development (the child is doing/performing himself/herself individually) and the zone proximal development where the child collaborates with the teacher (Vygotskij, 1997) and receives the teacher's support in a personally significant action, is useful in practice, working with 3-7 year old children.

The position of a democratic teacher (indirect management, teacherconsultant and collaboration partner) at work with preschoolers enables:

1) to agree with the children on the content of the songs to be mastered;

2) to collaborate equally with the child;

3) to consult and advise the child, as far as possible, to complete the task accurately;

4) to involve parents in collaboration (child-teacher-parent), encourage and stimulate them to support their children. Then the children feel good and safe, they want to collaborate, they are positive and responsive. Therefore, the position of the teacher, pedagogical tact and an individual approach to each child are important (the criterion for collaboration).

Sometimes the teacher is waiting for a faster musicality development result too soon, but each child develops differently and individually. This leads to the teacher's inner conflict, the expectations confronting opportunities and their implementation. A lengthy inner conflict causes external conflicts, and thus the teacher involuntarily pushes his/her will too much rather than encourages the child to act.

The teacher should encourage the child to act systematically, to be aware of the musical needs and to organize the day independently. The following sequence would be preferable for promoting the musical activity:

1) to create disposition;

2) set a goal;

3) to choose means;

4) enter activity: listening, singing, movements, mimics, simultaneous activity;

5) to reflect the results: contentedness for the accomplished (psychological), developed skill to emotionally respond and increased musicality quality (pedagogical). 


\section{Results: Outcomes of empiric research}

Observing the dynamics of emotional responsiveness of the child (247 respondents) during the first phase of the research, while developing the promotion work (1998-2002) and the second stage (a selection of 300 respondents) in the next 13 school years (2004-2016), it was concluded that observed emotional responses of 547 children were very different.

Comparing the emotional responsiveness of respondents and other components of musicality in both phases, it was concluded that in the second stage of the study children had a higher level of emotional responsiveness. Analyzing the teacher's activity, it was found that the emotional responsiveness of the children is affected by the change in the teacher's attitude towards children. Children's observations and discussions with their parents gave the opportunity to conclude that the musical environment at home is important for a timely musicality and emotional development.

Work with 3 y.o. and 4 y.o. preschoolers was complicated. Throughout the study, only some children were emotionally responsive in each group. This is due to the lack of a suitable musical environment at home.

Partial emotional responses could be observed after one month of work, when the child was adapted to the group, accepted the teacher and dealt with the pedagogical environment. During 13 years, only 10 children had an ageappropriate voice vocal range. Out of all 3-year-olds and 4-year-olds, only 20 were emotionally responsive to music, 50 were partially emotionally responsive, and 30 did not respond emotionally at all.

In order to make the children feel safer, in the first two months of each year, for three-year-olds and four-year-olds, music classes were organized together with their parents. In the integrated game activities, parents both observed children's activities and, with their children, participated in games and other activity types. As almost all children had an unclear articulation, it delayed the development of emotional responsiveness at the beginning, as children could not clearly pronounce the words.

By discussions with parents of 3 year-olds (100 respondents) after the open door sessions, it was found out that the parents sing together with their child in 20 families only. 80 children had no musical experience. Positive changes were observed after the TV show "Gimeņu dziedāšana"(Family singing). The example from real life practice influenced positively. The children even tried to sing the songs not appropriate for their voice vocal range.

Better results were observed with the 5 year-olds, who were learning music for the second year. Already at the very beginning of the school year, out of 100 respondents, 60 children were emotionally responsive, 20 children were 
Liduma, 2020. Unity of Theory and Practice in the Promotion of Preschool Child's Musicality in the Teacher's and Child's Collaboration

partly emotionally responsive, while other 20 children, who had started learning music for the first year, were emotionally unresponsive.

6 year-olds (100 respondents) with a previous emotional responsiveness experience adapted quickly and 70 children were emotionally responsive immediately. 20 children were partly emotionally responsive. 10 children, who had joined the group only at the age of 6 years, were emotionally unresponsive (See Figure 2).

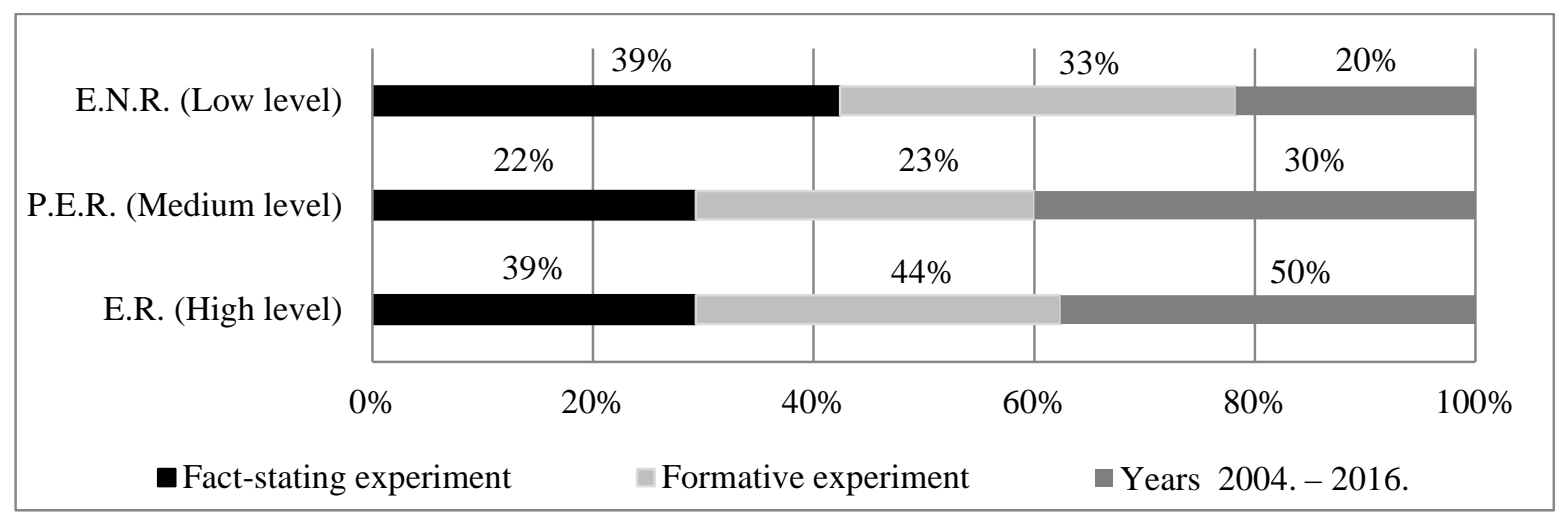

Figure 2 Dynamics of emotional responsiveness

A theory-based empirical study suggests that an individual approach and differentiated tasks for each child are needed. The teacher's mastery, positive attitude towards any child is important. In general, children's emotional responsiveness has improved and the dynamics is positive. Therefore, one of the important collaboration criteria is the musical environment.

In both stages of the study, children initially adapted and only then (approx. within a month) began to respond emotionally. Due to an illness or other delays, such adaptation cases repeated several times. The main benefit for the teacher was the improvement of collaborative competence.

It was the skill to work democratically, patiently, purposefully, unassumingly, timely changing forms of work, meeting the needs of children, and ensuring an individual approach to each child. After promotional work (1997-2004) defending in 2004, the developed theory of musicality promotion was applied by author of this research in the practice of the music pedagogue.

Collaboration with children parents was organized as well. The musical group teachers and children's initiative were joint concerts "We sing together". Parents, children, sisters and brothers, grandparents and friends participated. Each family presented a musical performance. Thus, in musical action, the succession of musicality development was promoted, the musical environment at home and the tradition of singing along in the family were promoted. The children and parents' attitude was positive about it. Observations in the pedagogues' practice 
confirmed that in pre-school age children, self-experience is acquired by observing and imitating adults. The adult's example stimulates perception, provokes emotional responsiveness, and child's musicality is fostered in collaboration.

Exercising with the child in practice, according to the criteria, indicators and levels of cross-correlations of the emotional responsiveness and the musicality promoting, in practice an individualized approach to each child for fostering of their emotional responsiveness and involving into activity with an appropriate musical content work session adjusted to the child's needs. Other significant factors are positive appraisal and positive performance by the teacher, ability to stimulate interest in the process of singing along - all together, as well as individually.

The child's ability to emotionally respond to music and the musicality development as a whole is promoted by the appropriate to the child's age musical environment at home and at preschool, when the child has started purposeful and persistent musical activity at an early age. Then meanwhile storing of the musical experience, apprehension of musical ideas and recalling into memory, remembering are being accomplished. Each musicality component is being promoted by the child's systematic personally significant activity.

\section{Conclusions}

This research revealed the cross-correlations of the emotional responsiveness and the musicality development, which are influenced by the objective (MC regulations, environment, content, methods, forms) and the subjective (pedagogue position/attitudes and the child position/attitudes) pedagogical means.

Particularly significant is the child's position/status in musicality development by activity: free choice, self-dependence and responsibility in equity based collaboration (parents-child-teacher).

The pedagogical preconditions for promoting musicality are: well-balanced and appropriate for child's age stage contents of classes in singing; integrated and appropriate for the relevant age group and his/her psyche and educating him/her songs and games - constitutes the world the child understands and is personally significant to him/her.

Succession in developing musicality is provided by a teacher, a child and his/her parents, in collaboration between a preschool child and a teacher in the upbringing process (teacher-child-parents). Efficiency of developing musicality for the children of preschool age is directly dependant on meeting succession and regularity principles and on implementing the contents, methods and techniques for mutual collaboration of children and different generations. 
Liduma, 2020. Unity of Theory and Practice in the Promotion of Preschool Child's Musicality in the Teacher's and Child's Collaboration

The theory/practice based research revealed that any changes to be implemented require a scientific basis developed by scientists of each particular country, which would promote the development of citizenship towards one's own country, and then towards other countries.

\section{References}

Balsons, M. (1996). Kā izprast klases uzvedību. Lielvārde: Lievārds.

Greata, J. (2006). An Introduction to Music in Early Childhood Education. Australia, Mexico, Singapore, Spain, United Kingdom, United States: Thomson Delmar Learning.

Līduma, A. (2004). Pirmsskolas vecuma bērnu muzikalitātes pedagogiskais aspekts. Rīga: LU. Līduma, A. (2015). Bērna muzikalitāte. Rīga: Librum.

Liduma, A. (2017). Collaboration in the kindergarten as a pedagogical means for developing positive attitudes. International dialogues on education: Past and Present. IDE, 4, 1, 100-106. Retrieved from http://www.ide-journal.org/journal/?issue=2017-volume-4number-1

Liduma, A. (2018). Scientific substantiation: for and against 6-year-old children commencing school education. Society, Integration, Education. Volume II, 585-601 DOI: 10.17770/sie2018vol1.3377

Mackeviča, L. (1999). Mērķtiecīga müzikas uztvere kā pirmsskolas vecuma bērnu audzināšanas lìdzeklis: Promocijas darba kopsavilkums. Liepāja.

Noteikumi par Valsts pirmsskolas izglīīibas vadlīijām - Likumi.lv. (2012). Pieejams https://likumi.lv/doc.php?id=250854

Pirmsskolas mācību programma. (2019). Valsts izglìtības satura centrs. ESF projekts Nr.8.3.1.1/16/I/002 Kompetenču pieeja mācību saturā. Pieejams https://mape.skola2030. $\mathrm{lv} /$ resources/10

Playwork Principles. Playwork Principles Scrutiny Group. (2004). Retriewed from http://www.playengland.org.uk/playwork-2/playwork-principles/

Špona, A. (2006). Audzināšanas process teorijā un praksē. Rīga: Raka.

Teplov, B.M. (1947). Psihologija muzykalnyh sposobnostej. Moskva: Leningrad: APN RSFSR.

Vikmane, B. (1995). Latviešu tautasdziesma kā pirmsskolas vecuma bērnu muzikālās dzirdes un balss attīstī̌sanas līdzeklis: Promocijas darba kopsavilkums. Rìga.

Wulf, Ch. (2007). Antropologie. Geschochte, Kultur, Philosophie. Reinbek bei Hamburg. Beltz Lexikon Pädagogik, 542-545

Vygotskij, L.S. (1997). Voprosy detskoj psihologii. SanktPeterburg: Sojuz. 